\title{
Keselarasan Islam dan Sains
}

\author{
Restiana Mustika Sari, dan Yudi Setiadi \\ restianamustika@gmail.com
}

\begin{abstract}
Abstrak: Tulisan ini mencoba mengulas hubungan antara Islam dan sains. Ada beberapa pendapat mengenai hubungan keduanya. Ada yang berpandangan bahwa antara Islam dan sains saling bertentangan antara satu dengan lainnya. Ada juga yang mengatakan bahwa Islam dan sains memiliki keselarasan bahkan memperkuat antara satu dan lainnya. Namun dalam tulisan ini akan memperkuat pendapat yang mengatakan bahwa Islam dan sains memiliki keselarasan antara satu dengan lainnya. Metode pengumpulan data dalam tulisan ini adalah studi pustaka. Sumber data dalam tulisan ini adalah buku, jurnal, dan literatur lainnya yang memiliki kaitan. Tulisan ini menyajikan beberapa fakta bahwa, Islam dan sains memiliki keselarasan bahkan memperkuat satu dengan lainnya. Kedua, Islam memiliki keselarasan dengan sains, hal ini dibuktikan dengan keselarasan ayat-ayat al-Qur'an, sebagai sumber utama Islam.
\end{abstract}

Keywords: Islam, Sains, Keselarasan

\section{A. Pendahuluan}

Hubungan antara Islam dan sains dapat diketahui melalui banyak sudut pandang. Keduanya ini mempunyai pengaruh pada manusia, di antaranya: Islam dan Sains sama-sama memberikan kekuatan, sains memberi manusia peralatan dan mempercepat laju kemajuan, Islam menetapkan maksud tujuan upaya manusia dan sekaligus mengarahkan upaya tersebut. Sains membawa revolusi lahiriah (material), Islam membawa revolusi batiniah (spiritual). Sains memperindah akal dan pikiran, Islam memperindah jiwa dan perasaan. Sains melindungi manusia dari penyakit, banjir, badai, dan bencana alam lain. Islam melindungi manusia dari keresahan, 
kegelisahan dan rasa tidak nyaman. Sains mengharmoniskan dunia dengan manusia dan Islam menyelaraskan dengan dirinya.

Seiring berkembangnya zaman, Eropa modern membangun sebuah sistem yang realistis, bahwa pengalaman yang diungkapkan dengan menggunakan akal saja tidak mampu memberikan semangat yang ada dalam keyakinan hidup, dan ternyata keyakinan itu hanya dapat diperoleh dari pengetahuan personal yang bersifat spiritual.

Hal inilah yang kemudian membuat akal semata tidak memberikan pengaruh pada manusia, sementara agama selalu meninggikan derajat orang dan mengubah masyarakat.

Dasar dari gagasan-gagasan tinggi kaum muslim adalah wahyu, Bagi intelektual muslim, basis spiritual dari kehidupan adalah tentang keyakinan. Demi keyakinan inilah seorang muslim yang kurang tercerahkan pun dapat mempertaruhkan jiwanya.

Al-Qur'an sebagai wahyu Allah yang bersumber langsung dari Allah telah memberikan informasi-informasi tentang alam semesta, khususnya yang berhubungan dengan matahari, bulan dan bumi. Ada 20 ayat yang menyebut kata matahari, dan ada 463 ayat yang menyebut kata bumi serta ada 5 ayat yang menyebut kata bulan. Belum lagi ayat yang menjelaskan tentang langit, pergantian siang dan malam, serta ayat yang menyebut tentang bintang-bintang. 
Dalam hal ini Islam secara terang melalui al-Qur'an mendorong umatnya untuk senantiasa melakukan pembaharuan di berbagai aspek kehidupan. Sebab dengan mempelajari dan mengembangkan sains (ilmu pengetahuan) umat Islam dapat mencapai kesadaran akan keagungan Allah. dan sains dapat mengharmoniskan dunia dengan manusia, dan Islam menyelaraskan dengan dirinya.

\section{B. Tinjauan Umum tentang Islam dan Sains}

1. Pengertian Islam dan Sains

Kata Islam memiliki konseptual yang luas, sehingga ia dipilih menjadi nama agama (din) yang baru diwahyukan Allah. melalui Nabi Muhammad kata Islam secara umum mempunyai dua kelompok kata dasar yaitu selamat, bebas, terhindar, terlepas dari, sembuh, meninggalkan. Bisa juga berarti: tunduk, patuh, pasrah, menerima. Kedua kelompok ini saling berkaitan dan tidak dapat terpisah satu sama lain. ${ }^{1}$

Adapun kata Islam secara terminologi dalam Ensiklopedi Agama dan Filsafat dijelaskan bahwa Islam adalah agama Allah yang diperintahkan-Nya kepada Nabi Muhammad untuk mengajarkan tentang pokok-pokok ajaran Islam kepada seluruh manusia dan mengajak mereka untuk memeluknya. ${ }^{2}$ 
Harun Nasution menerangkan bahwa Islam adalah agama yang ajaran-ajarannya diwahyukan kepada seluruh masyarakat melalui Nabi Muhammad sebagai Rasul. Islam pada hakikatnya membawa ajaranajaran yang bukan hanya mengenai satu segi tetapi mengenai bebagai segi dari kehidupan manusia. Sumber dari ajaran-ajaran yang mengadung berbagai aspek itu adalah al-Qur' an dan hadis. ${ }^{3}$

Kata sains dalam $W e b s t e^{\prime} s \quad N e w$ Werasald ari $D i c t c t$ bahasa latin yakni scire, yang artinya mengetahui. Jadi secara bahasa sains adalah keadaan atau fakta mengetahui. ${ }^{4}$ Sains juga sering digunakan dengan arti pengetahuan scientia. Secara istilah sains berarti mempelajari berbagai aspek dari alam semesta yang teroganisir, sistematik dan melalui berbagai metode saintifik yang terbakukan. Ruang lingkup sains terbatas pada beberapa yang dapat dipahami oleh indera (penglihatan, sentuhan, pendengaran, rabaan, dan pengecapan) atau dapat dikatakan bahwa sains itu pengetahuan yang diperoleh melalui pembelajaran dan pembuktian. ${ }^{5}$

\section{Asal Pengetahuan}

Ada sebuah pertanyaan tentang pengetahuan manusia, apakah dalam diri manusia terdapat sejumlah pengetahuan yang bersifat fitri? Ada tiga teori untuk menjawabnya. ${ }^{6}$ Teori pertama, dalam diri setiap manusia terdapat banyak konsep dan banyak pula hal-hal yang muktasabah (diperoleh melalui 
usaha). Seperti yang diterangkan Allah dalam Q.S al-Nahl: 78, “ $D a n$ A $l$ a $h$ mengeluarkan kamu dari perut ibumu dalam keadaan tidak mengetahui sesuatupun, dan Dia memberi kamu pendengaran, penglihatan dan hati, $\begin{array}{llllll}a & a r\end{array}$ a $m u \quad$ Secaræ lshiriyalk ayat tersẻbut menerangkan bahwa "Sesungguhnya ketika kamu dilahirkan, kamu belum mengetahui sesuatu apapun.” Artinya lembaran hati manusia masih dalam keadaan putih bersih, maka manusia diberi penglihatan, pendengaran, dan hati agar manusia dapat menuliskan berbagai hal dalam lembarannya hatinya.

Teori kedua, sesungguhnya manusia ketika dilahirkan sudah mengetahui segala sesuatu tanpa terlewatkan. Sebagai penjelasan, roh manusia sebelum ditempatkan di badan, ia berada di alam lain, yakni alam ide. Ide adalah hakikat dari segala sesuatu yang ada di alam semesta dan roh telah mengetahuinya. Ketika roh itu dimasukkan ke dalam badan maka muncullah penghalang yang memisahkan roh dari pengetahuan-pengetahuan ide tersebut. Rupanya teori kedua ini terpengaruh dari teori plato tentang ide, ia mencontohkan seorang bayi dilahirkan telah mengetahui segala sesuatu, adapun kemudian adanya proses pembelajaran adalah untuk mengingatkan sesuatu yang terlupakan.

Teori ketiga, manusia mengetahui sesuatu melalui fitrahnya. Sehingga pengetahuan yang diperoleh melalui cara ini sangat sedikit, prinsip berfikir itu bersifat fitrah. Dalam prinsip berfikir ini manusia membutuhkan 
6 | Restiana Mustika Sari dan Yudi Setiadi: Keselarasan Islam dan Sains

guru untuk membuat bangunan intelektualitas manusia agar sedemikian rupa. Sehingga cukup dengan menyodorkan beberapa hal saja sudah cukup baginya untuk mengetahui tanpa harus ada dalil dan bukti. Teori ketiga inilah yang umumnya dipakai oleh para filsuf muslim.

\section{Ilmu Pengetahuan dan Agama Islam}

Hubungan antara Islam dan sains dapat diketahui dengan dua sudut pandang. Pertama, apakah konsepsi dalam Islam melahirkan keimanan dan sekaligus rasional, atau semua gagasan ilmiah itu bertentangan dengan agama.

Sudut pandang kedua, merupakan landasan dalam membahas hubungan antara Islam dan sains, yakni bagaimana keduanya ini berpengaruh pada manusia. Agama dan sains sama-sama memberikan kekuatan, sains memberi manusia peralatan dan mempercepat laju kemajuan, agama menetapkan maksud tujuan upaya manusia dan sekaligus mengarahkan upaya tersebut. Sains membawa revolusi lahiriah (material), agama membawa revolusi batiniah (spiritual). Sains memperindah akal dan pikiran, agama memperindah jiwa dan perasaan. Sains melindungi manusia dari penyakit, banjir, badai, dan bencana alam lain. Agama melindungi manusia dari keresahan, kegelisahan dan rasa tidak nyaman. Sains mengharmoniskan dunia dengan manusia dan agama menyelaraskan dengan dirinya. 
Muhammad Iqbal menerangkan bahwa manusia membutuhkan tiga hal: pertama, interpretasi spiritual tentang alam semesta. Kedua, kemerdekaan spiritual. Ketiga, prinsip-prinsip pokok yang memiliki makna universal yang mengarahkan evolusi masyarakat manusia dengan berbasiskan rohani.”

Mengingat hal tersebut, Eropa modern membangun sebuah sistem yang realistis, bahwa pengalaman yang diungkapkan dengan menggunakan akal saja tidak mampu memberikan semangat yang ada dalam keyakinan hidup, dan ternyata keyakinan itu hanya dapat diperoleh dari pengetahuan personal yang bersifat spiritual. Hal inilah yang kemudian membuat akal semata tidak memberikan pengaruh pada manusia, sementara agama selalu meninggikan derajat orang dan mengubah masyarakat.

Dasar dari gagasan-gagasan tinggi kaum muslim adalah wahyu, wahyu berperan menginternalisasi (menjadikan dirinya sebagai bagian dari karakter manusia dengan cara manusia memperlajarinya) aspek-aspek lahiriahnya sendiri. Bagi intelektual muslim, basis spiritual dari kehidupan adalah tentang keyakinan. Demi keyakianan inilah seroang muslim yang kurang tercerahkan pun dapat mempertaruhkan jiwanya.

Will Durant (Penulis History of Civilization) pernah mengatakan: Harta itu membosankan, akal dan kearifan hanyalah sebuah cahaya redup 
8 | Restiana Mustika Sari dan Yudi Setiadi: Keselarasan Islam dan Sains

yang dingin. Hanya dengan cintalah kelembutan yang terlukiskan dapat menghangatkan hati.

Bisakah sains dan agama saling menggantikan posisi masing-masing? Pengalaman sejarah telah menunjukkan bahwa akibat dari memisahkan keduanya telah membawa kerugian yang tidak dapat ditutup. Agama harus dipahami dengan perkembangan sains, sehingga terjadi pembaruan agama dari cengkrama mitos-mitos. Agama tanpa sains berakhir dengan kemandekan. Sehingga apabila agama tanpa sains hanya akan dijadikan alat orang-orang munafik mencapai tujuannya.

Sains tanpa agama bagaikan lampu terang yang dipegang pencuri yang membantu pencuri lain untuk mencuri barang berharga di tengah malam. Atau bahkan sains tanpa agama adalah pedang tajam ditangan pemabuk yang kejam. $^{7}$

\section{E. Dinamika Pemikiran di Abad Pertengahan}

Ketika dunia barat mengalami masa kegelapan, khususnya di bidang ilmu pengetahuan akibat doktrin dari gereja, pada saat yang sama, geliat keilmuan Islam mengalami kemajuan seiring banyaknya pengkajian (research) dan pengembangan ilmu pengetahuan yang begitu pesat sehingga melahirkan peradaban yang bernilai tinggi. Ada dua faktor yang mempengaruhi kemajuan ini: pertama, faktor internal bahwa Islam sangat mendorong umatnya untuk mengembangkan ilmu pengetahuan, ditandai dari 
wahyu pertama yang turun kepada Nabi Muhammad adalah perintah $i \quad q \quad r \quad$, yang menunjukkan bahwa dunia Islam memberikan perhatian yang besar terhadap research dan pengembangan ilmu pengetahuan.

Dorongan faktor eksternal ialah diperoleh melalui kekuatan sistem pendidikan yang integral dan dinamis, di antaranya ketersediaan perpustakaan yang memadai pada setiap lembaga pendidikan. Kuatnya dukungan dari penguasa yakni menyediakan sarana yang lengkap untuk para ilmuan dalam mengembangkan teori-teori bahkan akan menghargai dengan sangat tinggi setiap temuan-temuan yang ada.

Pembahasan diatas membuktikan bahwa pada saat Eropa berada pada abad pertengahan (zaman kegelapan), umat Islam tengah mengalami kejayaan dan kemajuan peradabannya, kemajuan inipun dirasakan nonmuslim termasuk Barat. ${ }^{8}$ Seiring dengan mundurnya umat Islam di akhir abad pertengahan, sentuhan dunia barat dengan Islam pada akhirnya memunculkan tranformasi intelektual dari dunia Islam ke dunia Barat, sehingga melahirkan gerakan renaissance, reformasi, rasionalisme,dan aufklarung di dunia Barat.

Dengan demikian, kemajuan sains dan teknologi serta semangat intelektualisme yang berkembang begitu pesat di Barat pada saat ini, tidak terlepas dari kontribusi kemjaun umat Islam pada masa sebelumnya. ${ }^{9}$ 
10 | Restiana Mustika Sari dan Yudi Setiadi: Keselarasan Islam dan Sains

Salah satu faktor utama bagi timbulnya majunya peradaban Islam ketika abad pertengahan adalah membanjirnya proses penerjemahan berbagai literatur ke dalam bahasa Arab. Di antara literatur yang diterjemahkan tersebut adalah buku-buku India, Iran, dan buku Suriani-Ibrani, terutama sekali buku-buku Yunani. Pada pusat-pusat kebudayaan seperti Syria, Mesir, Persia, juga Mesopotamia, pemikiran filsafat Yunani ditemukan oleh orang muslim. Namun kota Baghdad yang menjadi pusat kekuasaan Dinasti Abbasiyah menjadi jalur utama masuknya filsafat Yunani ke dalam Islam, dan di sinilah timbul gerakan penerjemahan buku-buku Yunani ke dalam bahasa Arab. Berkat adanya usaha-usaha penerjemahan tersebut, umat Islam telah mampu mewarisi tradisi intelektual dari tiga jenis kebudayaan yang sangat maju, yakni Yunani, Persia, dan India. Warisan intelektual tersebut dimanfaatkan dalam membangun suatu kebudayaan ilmu pengetahuan yang lebih maju, seperti yang terlihat dalam berbagai bidang ilmu dan mazhab filsafat pemikiran Islam.

Di Bagdad, dibuka jasa penerjemahan. Bagi penerjemah buku-buku bahasa asing, akan dibayar dengan emas seberat buku yang diterjemahkan. Selain itu, di Baitul Hikmah, terdapat 400 ribu judul buku. Fenomena ini kemudian melahirkan cendikiawan-cendikiawan besar yang menghasilkan berbagai inovasi baru di berbagai disiplin ilmu pengetahuan. 
Berhasilnya pencapaian kemajuan Islam di berbagai bidang, khususnya ilmu pengetahuan yang demikian pesat dan beragam itu adalah berkat dorongan internal (faktor teologis) dan faktor eksternal yang antara lain berupa sentuhan dengan peradaban dan budaya luar yang berupa kontak intelektual dengan filsafat dan budaya Yunani pada masa itu. Persentuhan antar kebudayaan dimaksud sebenarnya sudah berlangsung sejak masa Umayyah, namun kemudian mencapai puncaknya pada era Abbasiyah berkat terlembagakannya upaya-upaya penterjemahan, yang kemudian dikenal dengan nama $K h \quad i \quad z \quad \bar{a}$-Hhikamah ondupun Bait al-Hikmah. ${ }^{10}$

Menurut Iqbal Dawami mengutip Myer, setidaknya ada empat hal yang menjadi akar atau potensi munculnya peradaban Islam dalam hal ilmu pengetahuan: ${ }^{11}$

1. Di tengah kemunduran Yunani dan munculnya Islam, berkembanglah sebuah kebudayaan yang memainkan peranan penting setelah kebudayaan Yunani dan juga merupakan sebuah perpaduan dari elemen-elemen timur, yaitu peradaban Helenisme, yang mulai muncul di permukaan setelah 300 SM. Tempat yang menjadi pusat intelektualnya adalah Alexandria. Sebuah institusi penelitian yang besar, de museum, telah dibangun di kota ini.

2. Filsafat Yunani mengalami stagnasi sejak tahun 529 M seiring dengan penutupan Akademi Athena secara resmi oleh Justianian. 
12 | Restiana Mustika Sari dan Yudi Setiadi: Keselarasan Islam dan Sains

3. Akademi Jundishapur di Parsi, sebuah akademi yang menjadi pusat pertukaran dan sinkretisme pengetahuan terbesar pada abad ke-7 M. Institusi ini menjadi surga bagi para Nestorian (pengikut Nestorius) yang diusir dari Edessa pada tahun $489 \mathrm{M}$ dan juga bagi para Platonis yang terusir. Para Nestorian itu membawa bersama mereka ke Jundishapur terjemahan-terjemahan Syiria dari berbagai macam karya, khususnya karya-karya dalam bidang pengobatan. Di Jundishapur pula Kisra Anushirwan memerintahkan penerjemahan karya-karya Aristoteles dan Plato ke dalam bahasa Parsi.

4. Aktivitas para Nestorian. Pada pertengahan pertama abad kelima masehi, pendeta Suriah, Nestorius, dipecat dan diusir dari kota Antioch ke wilayah Arab dan kemudian ke Mesir. Para pengikutnya dengan tulus dan penuh dedikasi mereka pindah sambil mengajarkan ilmunya ke wilayah Timur, tepatnya kota Edessa. Di sana terdapat sebuah akademi kedokteran yang sedang berkembang. Akademi itu menjadi pusat bagi aktivitas Nestorian dan memperoleh dukungan dari Akademi Nisbis di Mesopotamia dan juga dari Akademi Jundishapur.

Selain hal-hal di atas, munculnya akar peradaban Islam boleh jadi lantaran semangat keagamaan yang tinggi dalam memajukan ilmu 
pengetahuan, karena ayat suci al-Qur'an sendiri telah memotivasi kaum muslimin agar mereka selalu membaca dan membaca.

\section{F. Al-Kindi: Biografi, Pemikiran, dan Karya}

Para cendekiawan muslim, salah satunya al-Kindi, memiliki reputasi dan pengaruh yang diakui tidak hanya di dunia Islam abad pertengahan bahkan juga mewarnai filsuf-filsuf barat modern. Sedemikian besarnya pengaruh filsuf-filsuf muslim ini hingga W. Montgomery Watt mengambil kesimpulan bahwa tanpa keberadaan mereka, ilmu pengetahuan dan filsafat orang-orang Eropa tidak akan bisa berkembang seperti ketika dulu nenek moyang mereka mengembangkannya untuk pertama kalinya. ${ }^{12}$

Al-Kindi, alkindus, ${ }^{13}$ nama lengkapnya Abu Yusuf Ya'kub ibn Ishaq ibn Shabbah ibn Imran ibn Ismail Al-Ash'ats ibn Qais Al-Kindi, lahir di Kufah, Iraq sekarang, tahun 801 M, pada masa Khalifah Harun Al-Rasyid (786-809 M) dari Dinasti Bani Abbas (750-1258 M). Nama Al-Kindi sendiri dinisbahkan kepada marga atau suku leluhurnya, salah satu suku besar zaman pra-Islam. Menurut Faud Ahwani, Al-Kindi lahir dari keluarga bangsawan, terpelajar, dan kaya. Ismail Al-Ash'ats ibn Qais, buyutnya, telah memeluk Islam pada masa Nabi Muhammad dan menjadi sahabat Rasul. Mereka kemudian pindah ke Kufah. Di Kufah, 
14 | Restiana Mustika Sari dan Yudi Setiadi: Keselarasan Islam dan Sains

ayah Al-Kindi, Ishaq ibn Shabbah, menjabat sebagai gubernur, pada masa Khalifah Al-Mahdsi (775-785 M), Al-Hadi (785-876 M), dan Harun Al-Rasyid (786-909 M), masa kekuasaan Bani Abbas (750-1258 M). Ayahnya meninggal saat Al-Kindi masih kecil.

Al-Kindi melewati masa kecilnya di Kufah dengan menghafal alQur'an, mempelajari tata bahasa Arab, kesusastraan Arab dan ilmu hitung. Keseluruhan yang dipelajarinya di masa itu merupakan kurikulum pelajaran wajib bagi semua anak-anak zamannya di wilaah Kufah. Di ibu kota pemerintahan Bani Abbas ini, al-Kindi mencurahkan perhatiannya untuk menerjemah dan mengkaji filsafat serta pemikiranpemikiran rasional lainnya yang marak saat itu. ${ }^{14}$

Para cendikiawan berbeda pendapat tentang wafatnya al-Kindi, Mustaffa 'Abd al-Raziq misalnya mengatakan bahwa wafatnya al-Kindi pada tahun $252 \mathrm{H}$, sementara Massignon, Henry Corbin dan Nellino sepakat bahwa wafatnya al-Kindi terjadi pada tahun $260 \mathrm{H}$. Sedangkan Yaqut al-Himawi percaya bahwa al-Kindi Wafat sesudah berusia 80 tahun atau lebih sedikit. $^{15}$

Para sejarawan memberi julukan kepada Al-Kindi sebagai "Filsuf Arab" disebabkan dia adalah satu-satunya filsuf muslim keturunan Arab asli yang bermoyang kepada Ya'qub ibn Qahthan yang bermukim di 
kawasan Arab Selatan. Al-Kindi termasuk filsuf Islam yang sangat produktif. Dia telah menulis banyak karya yang meliputi berbagai macam bidang ilmu. Ibnu Nadhim mengatakan bahwa al-Kindi telah merilis 260 judul karya seperti, Filsafat, Logika, Kosmologi. Akan tetapi, sedikit saja jumlah karya al-Kindi yang sampai ke tangan orang-orang setelahnya. Sebagian riwayat mengklaim bahwa karya-karya al-Kindi hilang semasa kepemimpinan Khalifah al-Mutawakkil. Dalam sejarah hidupnya, di samping dikenal sebagai filsuf, al-Kindi juga tersohor sebagai kimiawan, seorang ahli musik, astronom, dokter, ahli geografi, bahkan seorang ahli musik. Dalam karya-aryanya, ia banyak menyoroti masalah logika dan matematika. Ia juga menulis ulasan-ulasan atas buku Aristoteles. ${ }^{16}$

Al-Kindi telah menulis hampir seluruh ilmu pengetahuan yang berkembang pada saat itu. Tetapi, di antara sekian banyak ilmu, ia sangat menghargai matematika. Hal ini disebabkan karena matematika, bagi alKindi, adalah mukadimah bagi siapa saja yang ingin mempelajari filsafat. Mukadimah ini begitu penting sehingga tidak mungkin bagi seseorang untuk mencapai keahlian dalam filsafat tanpa terlebih dulu menguasai matematika. Matematika di sini meliputi ilmu tentang bilangan, harmoni, geometri dan astronomi. ${ }^{17}$ 
16 | Restiana Mustika Sari dan Yudi Setiadi: Keselarasan Islam dan Sains

Adapun beberapa karya yang tulis al-Kindi adalah sebagai berikut: Pertama, fil al-falsafat al-Ula, Kedua, Kitab al-Ha $s$ s $i \quad$ a $l$ a $T a{ }^{\prime}$ a l tFalsafat. Ketiga, Risalat ila al-Ma' $m u n$-' $f \boldsymbol{l}$ aatl $\mathrm{w} a$

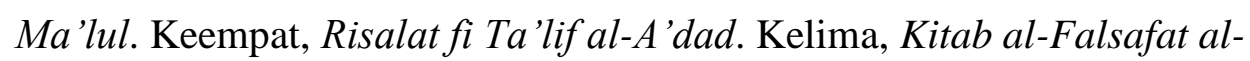
Dakhilatn wa al-Ma s a 'Malnthiqioylat wa al-Mu ' $t$ a $s$ ha $h \quad w a$ Faruqa al-T $h$ a $b$ i. Kexnæma Kammiyat Kutub Aristoteles, Ketujuh, Fi alNafs, dan lainnya. $^{18}$

Al-Kindi juga adalah salah satu orang yang terkenal di bidang pengobatan. Dalam dunia pengobatan al-Kindi menghasilkan karya antara lain: ${ }^{19}$

1. $R i$ s a l a h f $i$-Daiman lentang howhøptesṫsis(batuk darah dari saluran pernapasan).

2. Risalah fi Asyfiyat as-Sumum tentang penawar racun.

3. $R i$ s a $l$ a h-Judwain lwd Adsyfitatuhu, tentang penyakit lepra dan pengobatannya.

4. $R$ i s $\quad$ a $l$ a $h \quad f K a \dot{l} l b$ al-KAlib, hentang rabies.

5. $R i$ s a $l$ a $h \quad f i$-Anirdddh alHaddBhatelntang sèbab igauan dalam penyakit-penyakit akut. 
Al-Kindi juga dikenal sebagai cendekiawan yang mahir dalam bidang musik. Al-Kindi bahkan pernah menyusun notasi yang mirip dengan skala nada kromatik, sebagaimana dapat dilihat dalam tabel berikut: ${ }^{20}$

Symbols: A. B. J. D. H. W. Z. H. T. $\quad$ Y. K. L. Notes : a. bb b. c. c\# d. eb e. f. f\# g. ab

Notasi fonetis di atas telah digunakan jauh sebelum notasi fonetik diadopsi oleh Eropa Barat, bahkan sebelum masa al-Farabi. Kaum Muslim menggunakan notasi fonetis tersebut sejak awal abad ke-9 pada masa alMa'mun (w. 833) dan Ishaq al-Maushili (w. 850). Notasi tersebut juga ditemukan dalam karya-karya al-Kindi.

Selain itu juga, al-Kindi berjasa dalam mengembangkan ilmu mantiq di dunia Islam. Lebih dari itu, al-Kindi juga menjadikannya sebagai basis filosofis untuk pengembangan keilmuan yang mereka bangun. ${ }^{21}$ Dari uraian di atas dapat dijadikan bukti bahwa wawasan keilmuan al- Kindi sangatlah luas.

\section{G. Sains dan Ayat-ayat al-Qur'an}

Ketika kita berbicara tentang sains dan teknologi, maka kita tidak boleh melupakan peran cendekiawan Islam terhadap khazanah intelektual Timur dan Barat. Sebagai contoh Ibnu Sina, al-Ghazali, al-Biruni, alTabari, Nasiruddin, Abu al-Wafa, Al-Battani, dan Omar Khayam yang 
18 | Restiana Mustika Sari dan Yudi Setiadi: Keselarasan Islam dan Sains

berasal dari Persia. Al-Kindi, orang Arab, al-Khawarizmi adalah dari Khiva, al-Farghani dari Trasoxiania (Yordania), al-Farabi dari Khurasan, al-Zarkali (Arzachel), al-Betragius (al-Bitruji), dan Averroes (Ibn Rusyd) adalah Arab Spanyol. Kita tidak bisa menafikan sumbangan intelektual Muslim tentang matematik, ilmu kedokteran, ilmu astronomi, ilmu falak, ilmu arsitektur, ilmu geografi, dan lain-lain. ${ }^{22}$

Pada abad pertengahan, dunia Islam telah memainkan peranan penting baik di bidang sains teknologi. Harun Nasution menyatakan bahwa cendekiawan-cendekiawan Islam tidak hanya mempelajari sains-teknologi dan filsafat dari buku Yunani, tetapi menambahkan ke dalam hasil-hasil penyelidikan yang mereka lakukan dalam lapangan sains-teknologi dan hasil pemikiran mereka dalam ilmu Filsafat. Dengan demikian, lahirlah ahli-ahli ilmu pengetahuan dan filsuf-filsuf Islam, seperti, al-Farazi (abad VIII) sebagai astronom Islam yang pertama kali menyusun Astrolabe (alat yang digunakan untuk mengukur tinggi bintang) dan sebagainya. Para ilmuwan tersebut memiliki pengetahuan yang bersifat desekuaristik, yaitu ilmu pengetahuan umum yang mereka kembangkan tidak terlepas dari ilmu agama atau tidak terlepas dari nilai-nilai Islam. Ibnu Sina misalnya, di samping hafal al-Qur'an dia dikenal ahli di bidang kedokteran. al-Biruni, seorang ahli filsafat, astronomi, geografi, matematika, juga sejarah. Ibnu Rusyd, yang oleh dunia barat dikenal dengan Averous, dia bukan hanya terkenal dalam 
bidang filsafat, akan tetapi juga dalam bidang Fiqh. Bahkan kitab fiqih karangannya, yakni Bidayatul Mujtahid dipakai sebagai rujukan umat Islam di berbagai negara. ${ }^{23}$

Begitu tingginya nilai ilmu dalam peradaban manusia, Allah menegaskan dalam al-Qur`an bahwa Dia akan meninggikan derajat orangorang yang berilmu dan beriman sebagaimana dalam Al-Mujadalah ayat 11, Allah Berfirman:

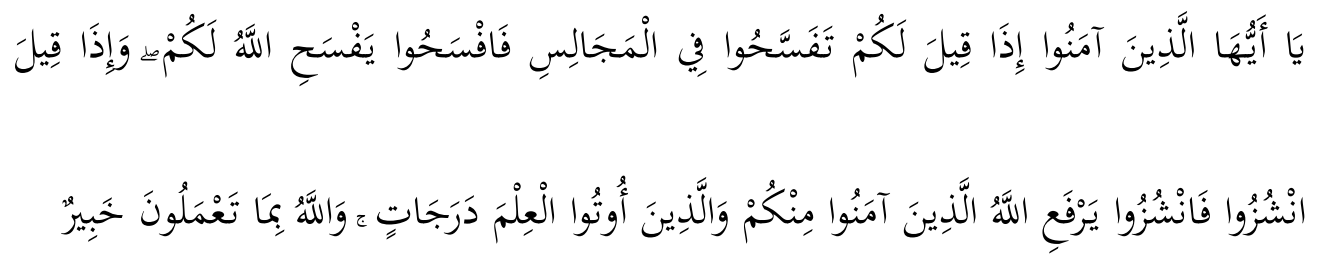

Hai orang-orang beriman apabila dikatakan kepadamu: "Berlapanglapanglah dalam majlis", maka lapangkanlah niscaya Allah akan memberi kelapangan untukmu. Dan apabila dikatakan: "Berdirilah kamu", maka berdirilah, niscaya Allah akan meninggikan orangorang yang beriman di antaramu dan orang-orang yang diberi ilmu pengetahuan beberapa derajat. Dan Allah Maha Mengetahui apa yang kamu kerjakan.

Ayat di atas menunjukkan kepada kita betapa Islam memberikan perhatian yang besar terhadap ilmu. Apapun bentuk ilmu itu, selama bisa memberikan kemanfaatan, maka ilmu tersebut harus dicari. Allah dan Rasul- 
Nya tidak menyebut suatu disiplin ilmu tertentu yang menjadi penyebab seseorang akan diangkat derajatnya oleh Allah, demikian juga tidak menyebut dengan menunjuk ilmu-ilmu tertentu untuk dipelajari.

Islam dan Sains tidak saling bertentangan, bahkan sebaliknya yakni memiliki keselarasan. Ada banyak ayat yang telah ditafsirkan oleh cendekiawan atau pengkaji al-Qur'an terkait dengan kesesuaiannya dengan sains.

Salah satu yang telah diteliti untuk menguatkan argumentasi di atas adalah ayat-ayat al-Qur'an yang memiliki kesesuaian dengan teori Heliosentris. Teori ini beranggapan bahwa matahari adalah merupakan pusat peredaran planet-planet, termasuk di dalamnya adalah bumi, sedangkan bulan adalah mengelilingi bumi yang kemudian bersama-sama bumi berputar mengelilingi matahari. Sedangkan matahari hanyalah berputar mengelilingi sumbunya saja. ${ }^{24}$

Al-Qur'an sebagai wahyu Allah yang bersumber langsung dari Allah telah memberikan informasi-informasi tentang alam semesta, khususnya yang berhubungan dengan matahari, bulan dan bumi. Ada 20 ayat yang menyebut kata matahari, dan ada 463 ayat yang menyebut kata bumi serta ada 5 ayat yang menyebut kata bulan. Belum lagi ayat yang menjelaskan 
tentang langit, pergantian siang dan malam, serta ayat yang menyebut tentang bintang-bintang.

Terkait dengan teori Heliocentris, ada beberapa ayat yang menjelaskan tentang gerak matahari, bulan dan bumi, yaitu surat Yunus: 5, surat Yasin: 38, dan surat al-Naml: 88. Beberapa ayat tersebut adalah:

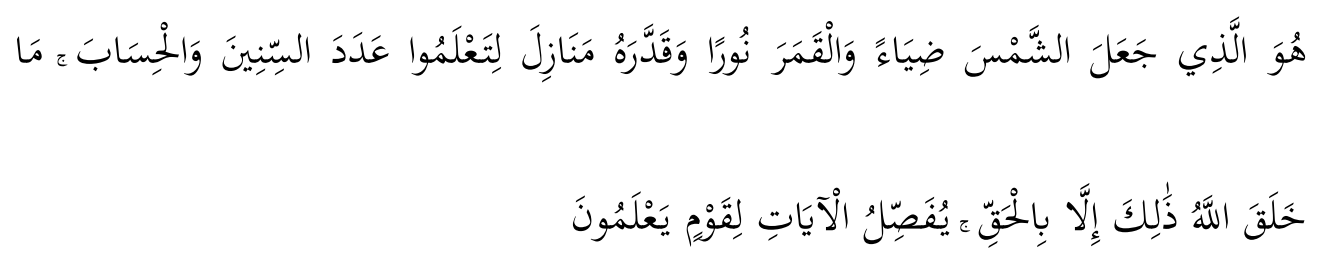

Dialah yang menjadikan matahari bersinar dan bulan bercahaya dan ditetapkan-Nya manzilah-manzilah (tempat-tempat) bagi perjalanan bulan itu, supaya kamu mengetahui bilangan tahun dan perhitungan (waktu). Allah tidak menciptakan yang demikian itu melainkan dengan hak. Dia menjelaskan tanda-tanda (kebesaran-Nya) kepada orang-orang yang mengetahui.

Secara khusus Allah menjelaskan perjalanan matahari dalam surat Yāsīn ayat 38:

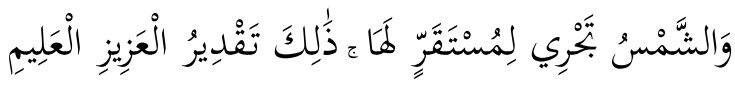


22 | Restiana Mustika Sari dan Yudi Setiadi: Keselarasan Islam dan Sains

Dan matahari berjalan ditempat peredarannya. Demikianlah ketetapan Yang Maha Perkasa lagi Maha Mengetahui.

Sedangkan mengenai gerak bumi, sebagaimana dijelaskan dalam surat al-Naml: 88:

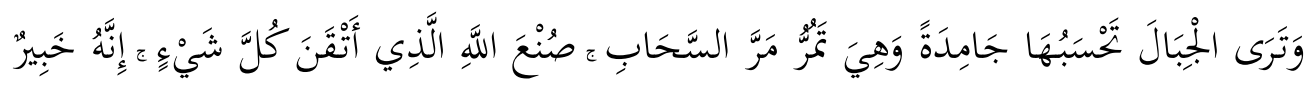

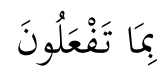

Dan kamu lihat gunung-gunung itu, kamu sangka dia tetap di tempatnya, padahal ia berjalan sebagai jalannya awan. (Begitulah) perbuatan Allah yang membuat dengan kokoh tiap-tiap sesuatu; sesungguhnya Allah Maha Mengetahui apa yang kamu kerjakan.

Selain itu, ada juga kajian yang telah menafsirkan ayat al-Qur'an yang memiliki kesesuaian dengan ilmu geologi yang ditulis oleh Izzatul Laila. Ia mengatakan bahwa lempeng-lempeng litosfer bergerak dan saling berinteraksi satu sama lain. Pada tempat-tempat tertentu saling bertemu dan pertemuan lempengan ini menimbulkan gempa bumi. Sebagai contoh adalah Indonesia yang merupakan tempat pertemuan tiga lempeng: Eurasia, Pasifik dan Indo-Australia. Bila dua lempeng bertemu maka terjadi tekanan (beban) yang terus menerus. Dan bila lempengan tidak tahan lagi menahan tekanan (beban) maka lepaslah beban yang telah terkumpul ratusan tahun itu, 
akhirnya dikeluarkan dalam bentuk gempa bumi. Sebagaimana termaktub dalam Surat al-Zalzalah, 99: $1-4:^{25}$

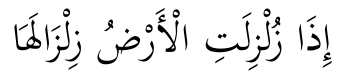

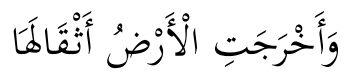

$$
\begin{aligned}
& \text { وَقَالَ الٍِْنْسَانُ مَا هَكَا }
\end{aligned}
$$

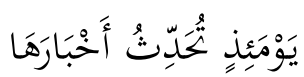

$$
\begin{aligned}
& \text { "Apabila bumi "digoncangkan dengan } \\
& \text { bertanya: ‘Mengapa bumi ( } j a d i \quad b e g i
\end{aligned}
$$$$
\text { Dan bumi t e lah 'bmeebnagne l buearraktanny ab.e'b aDha } n
$$

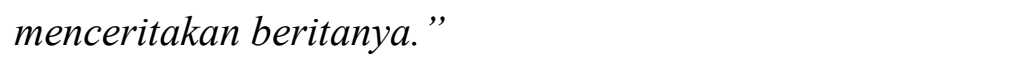

Beban berat yang dikeluarkan dalam bentuk gempa bumi merupakan suatu proses geologi yang berjalan bertahun-tahun. Begitupun seterusnya, setiap selesai beban dilepaskan, kembali proses pengumpulan beban terjadi. Proses geologi atau 'berita geologi' ini dapat direkam baik secara alami maupun dengan menggunakan peralatan geofisika ataupun geodesi. Sebagai contoh adalah gempa-gempa yang beberapa puluh atau ratus tahun yang lalu, peristiwa pelepasan beban direkam dengan baik oleh terumbu karang yang 
24 | Restiana Mustika Sari dan Yudi Setiadi: Keselarasan Islam dan Sains

berada dekat sumber gempa. Pada masa modern, pelepasan energi ini terekam oleh peralatan geodesi yang disebut GPS (Global Position System).

\section{H. Kesimpulan}

Berdasarkan pembahasan di atas, dapat disimpulkan bahwa antara Islam dan sains tidak bertentangan satu sama lain. Bahkan, antara Islam dan sains memiliki keselarasan dan dapat mempertegas antara satu dan yang lainnya.

Keselarasan Islam dan sains dapat dibuktikan dengan banyak hal. Salah satunya dengan produk berupa tokoh-tokoh Islam yang cemerlang dan memiliki kontribusi dalam bidang sains. Beberapa nama terkenal Islam tersebut diantaranya Ibnu Sina yang memiliki kontribusi dalam banyak bidang seperti kedokteran, filsafat, dan lain sebagainya.

Selain itu juga, ayat-ayat al-Qur'an, sumber utama dalam Islam, memiliki keselarasan dengan penemuan-penemuan sains masa kini. Beberapa diantaranya seperti ayat-ayat tentang bulan, bintang, dan matahari. Al-Qur'an telah lama memuat ayat-ayat yang berbicara tentang hal tersebut, dan telah dibuktikan kebenarannya oleh sains modern.

\footnotetext{
${ }^{1}$ Ma'luf, al-Munjid fi al-L u $g h a h-a \dot{w} d$, (Bairdt:'Dar al-Masyriq, 1975), hlm. 347

${ }^{2}$ Effendi, Ensiklopedi Agama dan Filsafat, Cet I, (Palembang: Univ. Brawijaya, 2001), hlm. 500 .

${ }^{3}$ Harun Nasution, Islam Ditinjau dari Berbagai Aspeknya, Jilid 1, Cet 1 (Jakarta: UI Press, 1979), hlm.17

${ }^{4}$ Lihat Pengertian Sains, https://alif.id//read//muhammad-ishom/pengertian-sains$\underline{\mathrm{b} 2157114 \mathrm{p} /}$
} 
${ }^{5}$ Jurnal Dakwah Tabligh, Vol. 14, No 1, Juni 2013, STAIN Palopo, karya Baso Hasyim, Islam dan Ilmu Pengetahuan (Pengaruh Temuan Sains Terhadap Perubahan Islam), 129

${ }^{6}$ Murtadha Muthahhari, Fitrah, (Jakarta, Lentera: 2008), 45

${ }^{7}$ Murtadha Muthahhari, Manusia dan Alam Semesta: Konsepsi Islam tentang Jagat Raya, (Jakarta: Lentera Basritama, 2002 ), 10-17

${ }^{8}$ Jurnal Islam Futura, Transformasi Intelektual Islam ke Barat, 24

${ }^{9}$ Syamsul Nizar, Sejarah Pendidikan Islam: Menelusuri Jejak Sejarah Pendidikan, (Jakarta: Kencana, 2016), 36

${ }^{10}$ Salahuddin, "Bait Al-Hikmah Dan Kontribusinya Dalam Perkembangan Tradisi Keilmuan Islam Pada Era Abbasiyah," HUNAFA: Jurnal Studia Islamika 8, no. 1 (2011): 156, https://doi.org/10.24239/jsi.v8i1.92.153-173.

${ }^{11}$ M. Iqbal Dawami, "Kontribusi Penerjemah Pada Zaman Keemasan Islam,"

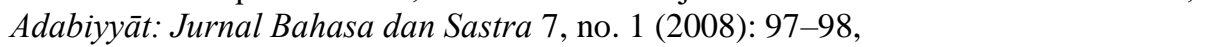
https://doi.org/10.14421/ajbs.2008.07106.

${ }^{12}$ Abubakar Madani, "Pemikiran Filsafat Al-Kindi,” Lentera IXX, no. 2 (2015): 107.

${ }^{13}$ Sri Sudewi dan Sri Mardikani Nugraha, "Sejarah Farmasi Islam dan Hasil Karya Tokoh-Tokohnya," Aqlam: Journal of Islam and Plurality 2, no. 1 (2017): 61, https://doi.org/10.30984/ajip.v2i1.511.

${ }^{14}$ Madani, "Pemikiran Filsafat Al-Kindi," 108. Kindi," 194

${ }^{15}$ Aravik dan Amri, "Menguak Hal-Hal Penting Dalam Pemikiran Filsafat al-

${ }^{16}$ Madani, "Pemikiran Filsafat Al-Kindi," 108-9.

${ }^{17}$ Nuning Khamidah, "Integrasi Pendidikan Karakter Berbasis Agama Islam dalam Pembelajaran Matematika di Madrasah Ibtidaiyah," Al-Bidayah: Jurnal Pendidikan Dasar Islam 6, no. 2 (2014): 244-45.

${ }^{18}$ Aravik dan Amri, "Menguak Hal-Hal Penting Dalam Pemikiran Filsafat alKindi," 194.

${ }^{19}$ Sudewi dan Nugraha, "Sejarah Farmasi Islam dan Hasil Karya TokohTokohnya," 61.

${ }^{20}$ Rahmat Hidayatullah, "Kontribusi Musik Arab-Islam Terhadap Musik Eropa Abad Pertengahan,” Bayan: Jurnal Kajian Ilmu-ilmu Islam VI, no. 1 (2016): 20.

${ }^{21}$ M. Muslih, "Sains Islam Dalam Diskursus Filsafat Ilmu," Kalam: Jurnal Studi Agama dan Pemikiran Islam 8, no. 1 (2014): 5, https://doi.org/10.24042/klm.v8i1.162.

${ }^{22}$ Muhammad AR., "Sains, Teknologi, Dan Nilai-Nilai Moral," Elkawnie: Journal of Islamic Science and Technology V 2, no. 2 (2016): 120-21, www.jurnal.arraniry.com/index.php/elkawnie.

${ }^{23}$ Nurul - Anam, “Al-Qur'an Dan Hadits: Dialektika Sains-Teknologi Dan Ilmu Agama," Al-Adalah 7, no. 1 (2008): 214.

${ }^{24}$ Slamet Hambali, “Astronomi Islam Dan Teori Heliocentris Nicolaus Copernicus," Al-Ahkam 23, no. 2 (2013): 228, https://doi.org/10.21580/ahkam.2013.23.2.24.

${ }^{25}$ Izzatul Laila, "Penafsiran Al-Qur'an Berbasis Ilmu Pengetahuan," Epistemé:

Jurnal Pengembangan Ilmu Keislaman 9, no. 1 (2014): 59-60, https://doi.org/10.21274/epis.2014.9.1.45-66.

\section{Daftar Pustaka}

Anam, Nurul -. "Al-Qur'an Dan Hadits: Dialektika Sains-Teknologi Dan Ilmu Agama." Al-Adalah 7, no. 1 (2008): 213-26. 
AR., Muhammad. "Sains, Teknologi, Dan Nilai-Nilai Moral." Elkawnie: Journal of Islamic Science and Technology V 2, no. 2 (2016): 109-26. www.jurnal.ar-raniry.com/index.php/elkawnie.

Dawami, M. Iqbal. "Kontribusi Penerjemah Pada Zaman Keemasan Islam."

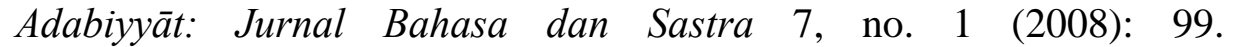
https://doi.org/10.14421/ajbs.2008.07106.

Effendi, "Ensiklopedi Agama dan Filsafat", Cet I, (Palembang: Univ. Brawijaya), 2001.

Hambali, Slamet. "Astronomi Islam Dan Teori Heliocentris Nicolaus Copernicus." Al-Ahkam 23, no. 2 (2013): 225. https://doi.org/10.21580/ahkam.2013.23.2.24.

Hidayatullah, Rahmat. "Kontribusi Musik Arab-Islam Terhadap Musik Eropa Abad Pertengahan.” Bayan: Jurnal Kajian Ilmu-ilmu Islam VI, no. 1 (2016): 165-83.

Khamidah, Nuning. "Integrasi Pendidikan Karakter Berbasis Agama Islam dalam Pembelajaran Matematika di Madrasah Ibtidaiyah.” Al-Bidayah: Jurnal Pendidikan Dasar Islam 6, no. 2 (2014): 235-51.

Laila, Izzatul. 'Penafsiran Al-Qur'an Berbasis Ilmu Pengetahuan.” Epistemé: Jurnal Pengembangan Ilmu Keislaman 9, no. 1 (2014). https://doi.org/10.21274/epis.2014.9.1.45-66.

Ma'luf, al-Munjid fi al-Lughah wa al'-a'lam, (Beirut: Dar al-Masyriq), 1975. Muthahhari, Murtadha. Fitrah, (Jakarta: Lentera), 2008.

------------, Manusia dan Alam Semesta: Konsepsi Islam tentang Jagat Raya, (Jakarta: Lentera Basritama) 2002.

Madani, Abubakar. "Pemikiran Filsafat Al-Kindi." Lentera IXX, no. 2 (2015): 106-17.

Muslih, M. "Sains Islam Dalam Diskursus Filsafat Ilmu." Kalam: Jurnal Studi Agama dan Pemikiran Islam 8, no. 1 (2014): 1. https://doi.org/10.24042/klm.v8i1.162.

Nasution, Harun, Islam Ditinjau dari Berbagai Aspeknya, Jilid 1, Cet 1 (Jakarta: UI Press) ,1979.

Nizar, Syamsul. Sejarah Pendidikan Islam: Menelusuri Jejak Sejarah Pendidikan, (Jakarta: Kencana) 2016.

Salahuddin. "Bait Al-Hikmah Dan Kontribusinya Dalam Perkembangan Tradisi Keilmuan Islam Pada Era Abbasiyah." HUNAFA: Jurnal Studia Islamika 8, no. 1 (2011): 153. https://doi.org/10.24239/jsi.v8i1.92.153173.

Sudewi, Sri, dan Sri Mardikani Nugraha. "Sejarah Farmasi Islam dan Hasil Karya Tokoh-Tokohnya." Aqlam: Journal of Islam and Plurality 2, no. 1 (2017): 57-72. https://doi.org/10.30984/ajip.v2i1.511. 